\title{
Psycho-sexual impact of the hysterectomy of African woman: experience of Cocody University Hospital (UH-C)
}

\section{Charles Kakou ${ }^{1 *}$, Denis Effoh ${ }^{1}$, Diomandé Ve ${ }^{2}$, Alexis Kouabenan ${ }^{1}$, Raphaël Abauleth $^{1}$, Serge Boni ${ }^{1}$}

\begin{abstract}
${ }^{1}$ Department Gynecology and Obstetrics, Cocody University Hospital, University Felix Houphouet Boigny, Abidjan, Côte d'Ivoire

${ }^{2}$ Department of Psychology, National Institute of Mental Health, Abidjan, Côte d'Ivoire
\end{abstract}

Received: 25 August 2017

Accepted: 02 September 2017

\author{
*Correspondence: \\ Dr. Charles Kakou, \\ E-mail: kakoucharles@yahoo.fr
}

Copyright: (c) the author(s), publisher and licensee Medip Academy. This is an open-access article distributed under the terms of the Creative Commons Attribution Non-Commercial License, which permits unrestricted non-commercial use, distribution, and reproduction in any medium, provided the original work is properly cited.

\begin{abstract}
Background: Specify the psychological and sexual impact of hysterectomy on the life of the women after the surgical operation.

Methods: It is a cross-sectional study which was undertaken in the obstetrical gynaecology department of the CHU of Cocody and in the National Institute of Mental Health of Abidjan over an 18-month period from December $1^{\text {st }}$, 2015 to May $31^{\text {st }}$, 2016. During that period, for gynaecological indications, hysterectomized patients who resumed sexual activities and accepted to take part in the study have been included.

Results: The frequency of hysterectomy has been $3.82 \%$ of the whole of more important surgical operations of the obstetrical gynaecology department. The epidemiologic profile of our patients has been that of a 43 years old woman, pauciparous and a single person. The indications were dominated by the uterine fibrome (56\%), followed by the peritonitis post abortum, the by the cancer of uterine cervix, and finally by the cancer of the ovarian tumors, with $10 \%$ each one. In less than 90 days, $88 \%$ of the women had resumed sexual intercourses. Six months after the hysterectomy, $66 \%$ of the women had a feeling of being better and $44 \%$ felt a change in their sexual life.

Conclusions: The hysterectomy undoubtedly brings about changes in the daily life, and sexual intercourses of the patients. Therefore, it must be taken into account whenever that intervention is essential.
\end{abstract}

Keywords: Hysterectomy, Sexuality, Welfare

\section{INTRODUCTION}

Symbol of femininity, maternity and sexuality, the uterus may be the site of pathologies that frequently require its removal. ${ }^{1}$ It is a major surgical act in gynecological surgery. She puts an end to the obstetrical future of the young woman.

Regardless of the indication, the psycho-sexual consequences of hysterectomy on woman are discussed and controversial in the literature, including developed countries. $^{2-4}$ In Africa, this is rarely discussed. The objective of our study was to clarify its impact on the psycho-sexual experiences of African women in sexual activity.

\section{METHODS}

It is a cross-sectional study which took place jointly in the of Gynecology and obstetrics Department of Cocody 
University Hospital and the National Institute of Mental Health of Abidjan from December $1^{\text {st }}, 2005$ to May $31^{\text {st }}$, 2007 either a period of 18 months. We have included in the study patients who had a hysterectomy in Gynecologic indication and who have agreed to participate in the study. These patients were to have resumed sexual activity. These patients have been reviewed 6 months after the intervention by the psychologist to clarify the psycho-sexual impact. The datas were analysed using the software Epi Info 2008 3.5.1.

\section{RESULTS}

\section{The frequency of hysterectomy}

During the study period, we recorded 78 hysterectomies on 2044 surgeries or $3.82 \%$. But only 50 were included in our study, $64.10 \%$ of hysterectomised according to the inclusion criteria.

\section{The epidemiological characteristics}

The average age of the patients was 43 years old with extremes of 24 and 53 years. Average equity was 3.1 with extreme of 0 and 7 . There were 34 single patients or $68 \%$.

\section{The characteristics of surgical operation}

There were various indications. Table 1 gives the summary. A bilateral adnexectomy was done in 15 patients or $30 \%$.

Table 1: Distribution of the studied population according to the indication of the hysterectomy.

\begin{tabular}{|lll|}
\hline Indications & Number & $\%$ \\
\hline Emergency Hysterectomy & 19 & 38 \\
\hline Haemorrhagic uterine fibroid & 12 & 24 \\
\hline Post abortum peritonitis & 5 & 10 \\
\hline Post abortum bleeding & 2 & 4 \\
\hline Hysterectomy programmed & 31 & 62 \\
\hline Haemorragic uterine fibroid & 16 & 32 \\
\hline Uterin prolapse & 2 & 4 \\
\hline Ovarian tumor & 5 & 10 \\
\hline Uterine cervix neoplasia & 5 & 10 \\
\hline Adenomyosis & 3 & 6 \\
\hline Total & 50 & 100 \\
\hline
\end{tabular}

Table 2: Moral status of the studied population according to the indication of the hysterectomy.

\begin{tabular}{|lll|}
\hline $\begin{array}{l}\text { Indications } \\
\text { Emergency } \\
\text { hysterectomy }\end{array}$ & 3 & $\begin{array}{l}\text { To feel much less } \\
\text { than others }\end{array}$ \\
\hline $\begin{array}{l}\text { Hysterectomy } \\
\text { programmed }\end{array}$ & 30 & 16 \\
\hline Total & 33 & 17 \\
\hline
\end{tabular}

$\mathrm{X}^{2}=34,43, \mathrm{p}=0,000$

\section{The post-hysterectomy experiences}

\section{The psychological experience}

At the question of know, how they felt morally, 33 patients or $66 \%$ reported feeling good. The study of the feeling of well-being based on the context of the intervention gave the results shown in the following Table 2. We noted that 39 patients or $78 \%$ felt that hysterectomy had an impact on their daily lives. Table 3 illustrates these daily changes.

Table 3: Distribution of the studied population according to the type of the impact induced by the intervention on the life of the patients.

\begin{tabular}{|lll|}
\hline Type of impact & Number & $\%$ \\
\hline Relief & 31 & 62 \\
\hline $\begin{array}{l}\text { Recovery of health, joy of } \\
\text { living }\end{array}$ & 24 & 48 \\
\hline No longer feels woman & 19 & 38 \\
\hline $\begin{array}{l}\text { Infertility, inability to procreate } \\
\begin{array}{l}\text { Dislocation of the matrimonial } \\
\text { home }\end{array}\end{array}$ & 17 & 34 \\
\hline $\begin{array}{l}\text { Aesthetic problem of the } \\
\text { abdominal wall }\end{array}$ & 1 & 10 \\
\hline Hot flashes & 1 & 2 \\
\hline
\end{tabular}

The sexuality

The delay of the sexual activity recovery has been variable. It was understood between 61 and 90 days in $54 \%$ of patients. This period was less than or equal to 60 days in $34 \%$. Only $12 \%$ patients had resumed sex 90 days after hysterectomy. Among the 50 patients, 22 (44\%) had felt a change in their sexual life. Table 4 recaps the nature of these changes.

Table 4: Classification of the patients according to changes appeared after the hysterectomy.

\begin{tabular}{|lll|}
\hline Sexual experience & Number & $\%$ \\
\hline Feels less desirable & 8 & 16 \\
\hline Libido be dropping & 12 & 24 \\
\hline Increased libido & 4 & 8 \\
\hline Plaisir be dropping & 7 & 14 \\
\hline Appearance of dyspareunia & 22 & 44 \\
\hline Sex more frequently & 12 & 24 \\
\hline
\end{tabular}

\section{DISCUSSION}

\section{Frequency and characteristics of patients}

The frequency of hysterectomy in the service was $3.82 \%$ over the period of study; it didn't change since 2002. It remains a frequent surgical operation. The patients included in our study were relatively young as evidenced 
by the average age of 43 years. However, they spent for the most reasonable age of new motherhood.

\section{Surgical operation}

Complicated uterine fibroids have been the major indication with $44 \%$ against $22.70 \%$ found by Abauleth et al in 2002 in the same service. ${ }^{5}$ Our results are in agreement with the literature. Indeed, uterine fibroids are the most common cause of hysterectomy for benign lesions. ${ }^{6}$ According to Waynberg, all the women operated are far from knowing the diagnosis requiring their hysterectomy. ${ }^{7}$ But generally speaking, the loss of the body triggers especially among the young woman of ambivalent psychological reactions. It is the case in Africa where the low education level of patients does not often to know the real cause of surgery. The practitioner is obliged to make a pictorial translation to be understood. In many cases despite these explications, the fear of surgery and the lack of financial means (because there is no social security fund) are responsible that the intervention is delayed for several months or even years. Finally, and by taking the example of uterine fibroids, myomectomy is no longer possible, it results in hysterectomy. Programmed interventions represented the majority of cases $(62 \%)$. This programming leave time to the doctor to inform goodly the patient about what it will be done by specifying the benefits, drawbacks and risks. So, the reasonably informed patient gives informed consent. This informed consent is obtained only after several meetings with the attending physician. The ovaries have been preserved in $70 \%$ of cases because of the relatively young age of the patients, 43 years on average. Our figures are close to those of Graesslin et al. who noted $40.4 \%$ to adnexectomy in their series, but the trend is toward the adnexectomy from 45 years. ${ }^{2}$

\section{Post hysterectomy psychological experience}

\section{The well-being feels}

In our series, $66 \%$ of women operated felt a sense of well-being after surgery. It was women who received surgery scheduled and who were hampered by their pathology (bleeding fibroids, cancer at beginning stage). Our observation is identical to those of other authors. ${ }^{3,8}$ For Graesslin et al, intervention frees the woman and improves his well-being if practiced for a true medical reason. ${ }^{2}$ Good acceptance of scheduled hysterectomy was also explained by the prior information given to patients. It should be noted that we don't focus our opinion on a particular type of psychiatric syndrome. In addition, the psychological state of patients had not assessed prior to surgery. However, the frequency of depression founded in the literature was between 11 to $29 \% .^{9}$ This "depression" and this bad tolerance could be explained chiefly by the fact that these women were not informed nor prepared psychologically. This tendency to depression was also founded by Womvolaki et al, for him, hysterectomy could result in the patient some signs of severe depression with feeling of sadness and disillusion. ${ }^{10}$ This bad tolerance was even observed in the young women or women having contracted a new marriage. It is an important factor in black Africa where the multiparity and making menstrual blood give special status to women in the society. So, during our investigation, we realized that being no longer able to procreate was a major concern in the population of women claiming not to feel. For them, the value of a woman is her ability to procreate and make its menstruations. It's a cultural data which must be considered when you have the choice of intervention.

\section{The impact induced by the intervention on the life of the patients}

The relief was the most mentioned impact by patients. This beneficial effect is described by Waynberg for who hysterectomy is lived sometimes as a relief when it puts an end to the functional and physical previous disease signs. ${ }^{7}$ In our study, we found 5 cases of dislocation of the matrimonial homes. This finding illustrates the social position of women still set and that can still procreate. Those won't present menstruation, are considered impure and relegated to second place. The husband then takes another wife, younger than, to have again children. These patients informed us of the departure of their husbands because they could no longer procreate.

\section{Post hysterectomy sexual experience}

The majority of women $(56 \%)$ reported retain all their sexual functions. Other authors like Zobbe et al found respectively $60 \%$ and $50 \%$ no changes in sexuality. ${ }^{11}$ The sexual recovery has been effective in 44 patients or $88 \%$ within 3 months after hysterectomy. Also note that $44 \%$ of women have seen a change in their sexual life. These changes, generally negatives, were also reported by some authors. ${ }^{12}$ About of 16 patients, who claimed to have observed a change in libido, 12 or $75 \%$ noted a decline; the others noted an increased libido. In our series, improvements in libido were reported by women for complicated uterine fibroids. This experience is shared by Buvat-Herbaut and Buvat. ${ }^{13}$ Indeed, these patients are relieved to no longer present dyspareunia or bleeding. As for the decline of libido, several explications are given by different authors: a physiological reduction of sexual desire from 45 years; estrogenic deficiency secondary to the oophorectomy. ${ }^{14}$ In our case, there was $30 \%$ of associated bilateral adnexectomy causing at the time a surgical menopause. For Cosson et al, the explication of this phenomenon is probably in relation with several factors (age and hormonal status). ${ }^{15} \mathrm{We}$ also noted that $14 \%$ (7 out of 50) patients reported a decrease in sexual pleasure. ROOVER et al have found that the majority of patients in their series didn't change of pleasure. ${ }^{4}$ After hysterectomy, $44 \%$ of the women in our series presented a dyspareunia. Authors such as Graesslin et al and Cosson et al found less high frequencies of dyspareunia respectively $15 \%$ and $11.3 \% .^{2,5}$ In our study, the 
dyspareunia was reported by 15 women who had a bilateral adnexectomy and 07 patients complaining of a decline in sexual pleasure. These pains may be related to anatomical changes. We say that in according with Graesslin et al, two main elements can come into play: the surgical technic and the remaining length of the vagina. $^{2}$ Here, a real problem is presented by the granuloma of the vaginal background, affecting nearly $21 \%$ of the patients according to Monyonda quoted by Graesslin et al. ${ }^{2}$ One of the causes found to this dyspareunia would be some cysts of inclusion on the vaginal scar. ${ }^{16}$ Indeed, pain when reports, evaluated by a score side of 0 to 10 , went from 9 before resection of cysts of inclusion, to 3 after intervention $(\mathrm{p}<0.001)$. Coital frequency went from 5 per month on average before resection to 11 per month after. ${ }^{16}$ In addition, secondary vaginal dryness to the bilateral adnexectomy is by far the main reason why this dyspareunia. Regarding the frequency of intercourse, 12 of our patients (24\%) reported an increase in the frequency of intercourse. These women feel liberated by the fact that they were more likely to contract an unwanted pregnancy.

\section{CONCLUSION}

Hysterectomy is a common intervention in Africa. This intervention has psycho-sexual influences in women. These influences are related to the context of realization of the intervention and associated surgical acts. The psychological preparation is essential to assist women in mourning the death of his "femininity".

Funding: No funding sources

Conflict of interest: None declared

Ethical approval: Not required

\section{REFERENCES}

1. Barrat J, Marpeau L, Leger D, Sicard A, Cerbonnet $\mathrm{G}$, Monod-Broca $\mathrm{P}$, et al. Reflexion à propos de l'hystérectomie. Indication, abus, retentissement psychologique, discussion. Bull Acad Natl Med. 1995;179:1855-70.

2. Graesslin O, Martin-Morille C, Leguillier Amour MC, Darnaud T, Gonzales N, Bancheri F, et al. Enquête régionale sur le retentissement psychique et sexuel à court terme de l'hystérectomie. Gynécol Obstét Fertil. 2002;30:474-82.

3. Hartmann KE, Lamvu GM, Lagenberg PW, Steege JF, Kjerulft KH. Quality of life and sexual function after hysterectomy in women with preoperative pain and depression. Obstet Gynecol. 2004;104:701-9.

4. Roovers JP, Vanderbom JG, Vandervaart $\mathrm{CH}$, Heintz AP. Hysterectomy and sexual wellbeing: prospective observational study of vaginal hysterectomy, subtotal abdominal hysterectomy, and abdominal hysterectomy. BMJ. 2003;327:774-8.

5. Abauleth YR, Koffi KA, Bokossa-Mambo ES, Yesufu A, Koné N. Hysterectomies at the maternity hospital of Cocody. Indications and results about 108 cases collected from 2001 to 2002. Médecine d'Afrique Noire. 2005;52:567-71.

6. Fernandez H, Gervaise A, de Tayrac R. Fibromes utérins. EMC Gynecol. 2002;1-11:570-A-10.

7. Waynberg J. Guide de sexologie médicale. Paris: Simep; 1994:64-7.

8. Lambden MP, Bellamy G, Ogburn-Russel L, Preece CK, Moore S, Pepin T, et al. Women's sese of wellbeing before and after hysterectomy. J Obstet Gynecol Neonat Nursing. 1997;26:540-8

9. Gath D, Cooper P, Day A. Hysterectomy and psychiatric disorder: level of psychiatric morbidity before and after hysterectomy. Brit J Psychiatr. 1982;140:335-50

10. Womvolaki E, Kalmantis K, Kioses E, Antaklis A. The effect of hysterectomy on sexuality and psychological changes. Eur J Contracept Reprod Helth Care. 2006;11:23-7.

11. Zobbe V, Gimbel H, Birthe MA, Filtenborg T. Sexuality after total versus subtotal hysterectomy. Acta Obstet Gynecol Scand. 2004;83:191-6.

12. Pieterse QD, Maas CP, Terkuile MM, Lowik M, Vaneijkeren MA, Trimbos JB, et al. An observational longitudinal study to evaluate miction, defecation, and sexual function after radical hysterectomy with pelvic lymphadenectomy for early stage cervical cancer. Int $\mathrm{J}$ Gynecol Cancer. 2006;16:119-29.

13. Buvat-Herbaut M, Buvat J. Hysterectomy and sexuality. N P N Med. 1991;179:527-8.

14. Proust S, Jouly F, Lopes P. Are the complications of hysterectomy related to the primary route? Update in Med Gynecol. 2004:182-207.

15. Cosson M, Rajabally R, Querleu D, Crepin G. Long term complications of vaginal hysterectomy: a casecontrol study. Eur J Obstet Gynecol Reprod Biol. 2001;94:239-44.

16. Sharp HT. Dyspareunia after hysterectomy: should the vaginal apex be resected? Am J Obstet Gynecol. 2000;183:1385-9.

Cite this article as: Kakou C, Effoh D, Ve D, Kouabenan A, Abauleth R, Boni S. Psycho-sexual impact of the hysterectomy of African woman: experience of Cocody University Hospital (UH-C). Int J Reprod Contracept Obstet Gynecol 2017;6: 4281-4. 